\title{
Adventitious branching as a herbivore-induced defense in the intertidal brown alga Fucus distichus
}

\author{
Kathryn L. Van Alstyne* \\ Department oi Zoology, NJ-15, University of Washington, Seattle, Washington, 98195, USA \\ and \\ Friday Harbor Laboratories, Friday Harbor, Washington 98195 , USA
}

\begin{abstract}
Adventitious branches are produced following injury in at least 5 species of brown algae in the family Fucaceae. Field experiments showed that these structures can be induced in the intertidal brown alga Fucus distichus by mechanical damage to the plant apices. The mean number of adventitous branches on $F$. distichus and the percent of plants with adventitious branches was positively correlated with the density of littorine snails Littorina sitkana and L. scutulata near the plants at 8 locations within the main beach of Tatoosh Island, Washington, USA, suggesting that the production of these structures is a response to grazing by the snails. In laboratory feeding experiments, both L. sitkana and $L$. scutulata preferred normal meristematic tissue (apices) over adventitious branches. Thus, adventitious branches appear to function as an herbivore-induced defense that protects newly produced tissues from damage by grazers. Neither $L$. sitkana nor $L$. scutulata showed a preference for wings over adventitious branches. Concentrations of polyphenolic compounds were about 10 to $70 \%$ higher in adventitious branches than apices but were 20 to $50 \%$ lower than phenolic levels in wings.
\end{abstract}

\section{INTRODUCTION}

Many organisms protect themselves from predators by being chemically or morphologically defended (Rosenthal \& Janzen 1979, Harborne 1982, 1986, Hay \& Fenical 1988, Van Alstyne \& Paul 1988). Although these defenses confer a selective advantage upon the organisms that produce them, they are also presumed to have a cost associated with their production (Rhoades 1979). Therefore, many organisms do not produce defenses continuously, but instead produce them only when the risk of predation is high. Damage by predators is frequently used as a cue for the production of new or additional defenses. Predator-induced defenses are common and have been reported to occur in protozoans, rotifers, cladocerans, bryozoans (Harvell 1985, 1986), barnacles (Lively 1986a, b) seaweeds (Lewis et al. 1987, Van Alstyne 1988a) and vascular plants (see review by Havel 1986). In general, predator-induced defenses are of 2 types: they protect either

\footnotetext{
- Present address: University of Guam Marine Lab, UOG Station, Mangilao, Guam 96923, USA
}

existing tissues or newly produced structures. Examples of defenses that protect existing tissues are increased production of plant secondary metabolites following grazing (Havel 1986) and the production of spines in existing zooids of bryozoans (Harvell 1984, 1985). Embryonic induction of morphological defenses in zooplankton (Gilbert 1966, 1967, 1980) and the production of adventitious shoots in trees (Bryant 1981, 1982) are examples of the latter type of induced defense.

Fucus distichus ssp. edentatus de la Pyl. (Pow.) (=F. garderni), an intertidal temperate brown algal rockweed, is among the least preferred foods of the herbivorous snails Littorina sitkana and Littorina scutulata (Van Alstyne 1988b). Like many fucoid brown algae, $F$. distichus produces large quantities of polyphenolic compounds (Steinberg 1985, Van Alstyne 1988a, b). The presence of these types of compounds is associated with low rates of feeding by many temperate herbivores including littorine snails (Geiselman 1980, Geiselman \& McConnell 1981, Van Alstyne 1988b), turban snails (Steinberg 1985) and echinoderms (Anderson \& Velimirov 1982). The production of 
phenolic compounds by brown algae has recently been reviewed by Ragan \& Glombitza (1986).

When Fucus distichus is physically damaged, the production of chemical defenses in existing tissues is induced (Van Alstyne 1988a). Over a 2 wk period following damage, concentrations of polyphenolic compounds increase throughout the midribs of the alga by ca $20 \%$. The increase in polyphenolic levels in these tissues appears to provide substantial protection against the herbivorous snail Littorina sitkana. Previously damaged plants with higher levels of defenses are consumed about $50 \%$ less than undamaged plants. Thus, this induced chemical defense protects existing tissue against future grazing. In addition, Fucus spp. also produce regenerative outgrowths when they are wounded (Oltmanns 1904, Fritsch 1959). These growths, termed adventive or adventitious embryos, occur most often from the plant midrib (Fulcher \& McCully 1969) and occasionally from the wings of the injured plants (Moss 1961).

Adventive embryo formation begins with a thickening of the tissue immediately adjacent to the site of the injury (Moss 1961). After about $1 \mathrm{wk}$ in culture, the medullary cells adjacent to the wound surface give rise to elongating filaments which grow through the wound surface. Here, the apical cells of the filaments divide repeatedly and eventually proliferate into small branches that resemble developing Fucus embryos. The term 'adventive embryo' is therefore a misnomer since these tissues arise from medullary cells and are not embryonic in origin. For this reason I will refer to these structures as adventitious branches throughout the rest of this paper. Electron microscopic studies have shown that there is an initial loss of polyphenolic compounds from the wound surface (Fulcher \& McCully 1971), however the polyphenols became re-established in these tissues 5 to $10 \mathrm{~d}$ after injury

Terrestrial vascular plants produce similar outgrowths in regenerating tissues (Steward 1968). Moreover, adventitious branches in terrestrial plants have higher concentrations of defensive compounds than normal branches and are less palatable to grazers (Bryant 1981). Moss (1961) and Fulcher \& McCully (1969) suggested that the formation of adventitious branches in brown algae can occur following damage to the plants caused by herbivory. Thus, adventitious branches of fucoid brown algae may be analogous to adventitious shoots produced by many tree species; however, the role of these structures in reducing grazing has not been addressed.

In this study, I examine the phenomenon of adventitious branch production following grazing as a means of protecting newly regenerating algal tissues from grazers. Field measurements were made that correlate adventitious branch production with grazer densities within a single location. Laboratory feeding experiments examined the susceptibility of adventitious branches, apices, and wing tissue to the herbivorous snails Littorina sitkana and L. scutulata.

\section{METHODS}

Field measurements and experiments. Previous laboratory studies have shown that the production of adventitious branches is initiated by damage to the algal thallus (Fulcher \& McCully 1969, 1971, Moss 1961); however, there have been no studies of the natural causes of adventitious branch production. If adventitious branches in nature result from grazing by herbivores then their abundances should be correlated with herbivore activity. A survey was made of 10 locations on Tatoosh Island, Washington, USA. These included: Pole Island Draw, Strawberry Draw, and 8 locations on the main beach of the island. In each location, I measured the number of adventitious branches occurring on the first 10 to 20 reproductive plants that I encountered within a randomly selected $1 \mathrm{~m}$ by $1 \mathrm{~m}$ area. Herbivore densities were also quantified by counting the number of Littorina sitkana and $L$. scutulata occurring within a 10 by $10 \mathrm{~cm}$ quadrat haphazardly placed in 3 areas within the same $1 \mathrm{~m}$ by $1 \mathrm{~m}$ area at each location. Littorina spp. were the only Fucus-consuming herbivores encountered in the quadrats. The Pole Island Draw, Strawberry Draw and main beach sites differed greatly in exposure, degree of shading, and substrate composition; however, the sites on the main beach of Tatoosh Island were similar to one another. The main beach sites were chosen to be within $50 \mathrm{~m}$ of one another and at approximately the same tidal height in an attempt to minimize the effects of stresses caused by other factors such as available sunlight, water motion and desiccation. A least squares linear regression was used to test for correlations between mean Littorina spp. densities and (1) mean numbers of adventitious branches on $F$ distichus; (2) percent of Fucus distichus with adventitious branches of the 8 sites on the main beach.

A set of clipping experiments was carried out at the Friday Harbor Laboratories on San Juan Island, Washington, to determine if mechanical damage to Fucus distichus could induce the formation of adventitious branches in the field. In July 1987, 30 nonreproductive plants ranging from 10 to $20 \mathrm{~cm}$ in length (holdfast to most distal apex) were tagged with 6 to $8 \mathrm{~mm}$ wide strips of surveyor's tape. The plants were all growing on a large $(\mathrm{ca} 2 \mathrm{~m}$ long $\times 1 \mathrm{~m}$ wide $\times 2 \mathrm{~m}$ high) boulder. On 20 of these plants, 5 of the apices on each alga were clipped ca $1 \mathrm{~cm}$ from the ends. Herbivorous snails frequently graze the margins of the 
blades and the apices of the plants, so this type of damage is similar to damage that might occur by grazing. The remaining 10 plants were left unclipped and served as controls. In October 1987 the apices of the 13 clipped and 8 control plants that remained were examined for evidence of adventitious branch formation. The maximum lengths of the adventitious branches were also measured.

Preference experiments. Relative preference of Littorina sitkana and L. scutulata for adventitious branches, wing tissue, and apical meristematic tissue (Fig.

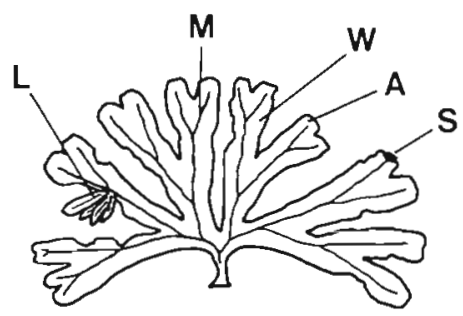

Fig. 1. Fucus distichus. A: Apical meristem; L: long adventitious branch growing from midrib; $M$ : midrib; $S$ : short adventitious branch growing from apex; $W$ : wing

1) were determined in laboratory feeding experiments In these experiments, comparisons of consumption rates by both $L$. sitkana and $L$. scutulata were made between the following pairs of tissues: short $1<1 \mathrm{~cm}$ long) adventitious branches versus apices, medium (1 to $2 \mathrm{~cm}$ long) adventitious branches versus apices, long ( 2 to $3 \mathrm{~cm}$ long) adventitious branches versus apices, short adventitious branches versus wings, medium adventitious branches versus wings and long adventitious branches versus wings.

Fucus distichus on which adventitious branches were growing were collected from in front of the Friday Harbor Laboratories. The plants were maintained in laboratory seawater tables for 1 to $2 \mathrm{~d}$ prior to the experiments. Littorine snails used in these feeding experiments were collected from Tatoosh Island or from the Mar Vista resort on San Juan Island. They were maintained in flow-through seawater tables and were starved for at least $24 \mathrm{~h}$ prior to each experiment. All feeding experiments were conducted in flowthrough seawater tables at the Friday Harbor Laboratories. The experiments were conducted in plastic sandwich containers that had been partitioned into 4 separate quadrants with $5 \mathrm{~mm}$ thick pieces of cedar shingles. Each quadrant was ca $6 \mathrm{~cm}$ long $\times 6 \mathrm{~cm}$ wide $\times 4 \mathrm{~cm}$ high.

Adventitious branches, wings, and apical meristematic tissues were excised from plants with a sharp razor blade. The plant tissues were blotted dry with paper towels before being weighed. Two similarly sized pieces $(0.1$ to $0.6 \mathrm{~g})$ of adventitious branches and apices or adventitious branches and wing tissues were placed into a single quadrant of the partitioned plastic boxes along with 5 to 15 snails. Five L. sitkana or $10 \mathrm{~L}$. scutulata were added to each quadrant in experiments in which one of the pair was a short adventitious branch. Ten L. sitkana or 15 L. scutulata were added to each quadrant in preference experiments involving medium and long adventitious branches. Plant pieces were weighed prior to adding the snails and then $4 \mathrm{~d}$ later in order to quantify the amount of each tissue type eaten by the littorines. Grazing rates were compared for each combination of tissues using each littorine species. There were 8 replicates for each combination of snails and plant tissues. Four quadrants holding pieces of tissue in the absence of snails served as controls for these experiments.

Results for all preference experiments were analyzed using a Student's $t$-test for data with unequal variances (Sokal \& Rohlf 1981). The amount of algal tissue consumed by the snails was calculated as the initial weight minus the final weight for each tissue in an individual feeding experiment. The consumption rate of the apices or wing tissues was then subtracted from the consumption rate of the adventitious branches in each replicate giving a single data point for each replicate of the experiment. The relative differences in mass changes of the pair of tissues were then compared for the 8 containers with snails and the 4 control containers without snails using a Student's t-test for data with unequal variances. This procedure for analyzing the results of 2-way preference experiments is described in Peterson \& Renaud (in press).

Phenolic measurements. Concentrations of polyphenolic compounds were measured in apical meristems, wings, and short, medium and long adventitious branches. Nine or 10 replicate measurements were made of each tissue type. Pieces of tissue 10.25 to $0.5 \mathrm{~g}$ ) were extracted by grinding them in $15 \mathrm{ml}$ of $70 \%$ methanol:distilled water with a Virtis ' 45 ' homogenizer. The extract was then filtered through a Whatmann GF/A glass fibre filter and the filtrate was analyzed for phenolics using a Folin-Denis analysis for total phenolics according to the method described by Swain \& Goldstein (1964). In order to confirm the presence of polyphenolic compounds in these extracts, we also used staining with Lindt's reagent, a stain specific to phloroglucinol derivatives (Ragan \& Craigie 1978), to assay the presence or absence of polyphenolics. Differences in polyphenolic concentrations between tissue types were compared using a 1-way analysis of variance and mear concentrations were compared using a Student-Newman-Keuls (SNK) test (Sokal \& Rohlf 1981). 


\section{RESULTS}

Adventitious branching occurs commonly among species of fucoid macroalgae (Table 1). On Tatoosh Island, 40 to $100 \%$ of the Fucus distichus at the 10 locations surveyed around the island had at least one adventitious branch (Table 2). The mean numbers of adventitious branches ranged from 0.5 per plant at the site with the lowest density of herbivores to 4.7 per plant at a site with relatively higher Littorina spp. densities; however, F. distichus at the site with the highest snail densities, Pole Island Draw, did not have the highest proportions of plants with adventitious branches nor the greatest densities of adventitious branches per plant.

The presence of adventitious branches within a single location, the main beach of Tatoosh Island, corresponded well with Littorina spp. densities. Mean numbers of adventitious branches on adult Fucus distichus were highly correlated $(r=0.904, p<0.001$, using a least squares linear regression) with the abundance of their 2 major grazers, Littorina sitkana and L. scutulata, in very localized areas beneath the plants. The percent age of plants that contained adventitious branches was also highly correlated with the density of Littorina spp. ( $r$ $=0.885, p=0.004$, using a least squares linear regression). The damage that I observed on these wounded plants appeared to be primarily a result of grazing. Both $L$. sitkana and $L$. scutulata were often observed to be feeding on the damaged plants. In addition, most of these plants showed holes and scraped surface in the wings and receptacles that are characteristic of littorine grazing (pers. obs.) rather than having the tears in the thallus and abraded surfaces that are characteristic of damage produced by waves.

The laboratory clipping experiments demonstrated that adventitious branching in Fucus distichus can be induced in the field by mechanical damage to the plants. Of the clipped apices, $35 \%$ developed adventitious branches whereas none of the unclipped contral plants did (Table 3). Adventitious branch formation

Table 1. Occurrence of adventitious branching in members of the brown algal family Fucaceae

\begin{tabular}{lll}
\hline Species & Location & Saurce \\
\hline Fucus vesiculosus & - & Moss (1961) \\
& - & McLachlan \& Chen (1972) \\
& Ketch Harbor, Nova Scotia, Canada & Fulcher \& McCully (1969) \\
& Morris Point, Nova Scotia, Canada & Fulcher \& McCully (1969) \\
Fucus distichus & Narragansett, Rhode Island, USA & K. Van Alstyne pers. obs. \\
Fucus spiralis & Tatoosh Island, Washington, USA & K. Van Alstyne pers. obs. \\
Pelvetia canaliculata & Friday Harbor, Washington, USA & K. Van Alstyne pers. obs. \\
Pelvetiopsis limitata & Tatoosh Island, Washington, USA & K. Van Alstyne pers. obs. \\
-: location not given & Friday Harbor, Washington, USA & K. Van Alstyne pers. obs. \\
& Tatoosh Island, Washington, USA & Moss (1961) \\
& & K. Van Alstyne pers. obs.
\end{tabular}

Table 2. Littorina spp. and Fucus distichus. Herbivore densities and adventitious branch production at 10 sites on Tatoosh Island Washington, USA. Herbivore densities (as no. $\mathrm{m}^{-2}$ ) are means of numbers of herbivores in a $10 \mathrm{~cm} \times 10 \mathrm{~cm}$ quadrat within 3 haphazardly chosen locations at each site. The percent of $F$. distichus with adventitious branches (AB) and the mean number ( \pm 1 $\mathrm{SD}$ ) of adventitious branches per plant were obtained from counts from reproductive plants sampled from within a $1 \mathrm{~m} \times 1 \mathrm{~m}$ area at each location

\begin{tabular}{|c|c|c|c|c|c|}
\hline Location & $\begin{array}{l}\text { L. sitkana } \\
\text { density }\end{array}$ & $\begin{array}{l}\text { L. scutulata } \\
\text { density }\end{array}$ & $\begin{array}{l}\% \text { with } \\
\text { AB's }\end{array}$ & No. of AB's & $N$ \\
\hline Strawberry Draw & $1600 \pm 100$ & $133 \pm 115$ & 65 & $1.7 \pm 1.8$ & 20 \\
\hline $\begin{array}{l}\text { Pole Island Draw } \\
\text { Main Beach }\end{array}$ & $3100 \pm 361$ & $500 \pm 265$ & 65 & $1.5 \pm 1.4$ & 20 \\
\hline Site I & $0 \pm \quad 0$ & $0 \pm 0$ & 40 & $0.5 \pm 0.6$ & 20 \\
\hline Site II & $233 \pm 208$ & $100=100$ & 35 & $0.6 \pm 1.0$ & 20 \\
\hline Site III & $633 \pm 289$ & $167 \pm 58$ & 71 & $1.6 \pm 2.8$ & 14 \\
\hline Site IV & $567 \pm 153$ & $267 \pm 289$ & 80 & $1.6 \pm 1.7$ & 10 \\
\hline Site V & $1107 \pm 1315$ & $68=115$ & 60 & $1.9 \pm 2.5$ & 20 \\
\hline Site VI & $1133 \pm 473$ & $233 \pm 58$ & 90 & $3.4 \pm 2.3$ & 20 \\
\hline Site VII & $1233 \pm 643$ & $200 \pm 100$ & 80 & $2.5 \pm 3.0$ & 10 \\
\hline Site VIIJ & $1600 \pm 173$ & $400 \pm 265$ & 100 & $4.7 \pm 2.8$ & 10 \\
\hline
\end{tabular}


Table 3. Fucus distichus. Production of adventitious branches on clipped and unclipped apices

\begin{tabular}{|lcc|}
\hline & Clipped & Unclipped \\
\hline $\begin{array}{l}\text { Proportion of plants with } \\
\text { adventitious branches }\end{array}$ & $62 \%$ & $0 \%$ \\
$\begin{array}{l}\text { Percent of apices per plant with } \\
\text { adventitous branches ( } \bar{x} \pm 1 \mathrm{SD})\end{array}$ & $35.4 \pm 40.0$ & $0.0 \pm 0.0$ \\
\hline
\end{tabular}

occurred on at least one of the damaged apices in $62 \%$ of the clipped plants. Three months after clipping the apices, the adventitious branches ranged in length from $<1$ to $5 \mathrm{~mm}$. The mean length $( \pm 1 \mathrm{SD})$ was $1.3 \pm 1.8 \mathrm{~mm}$, with $59 \%$ of the adventitious branches being $<1 \mathrm{~mm}$ long

Laboratory preference experiments showed that both
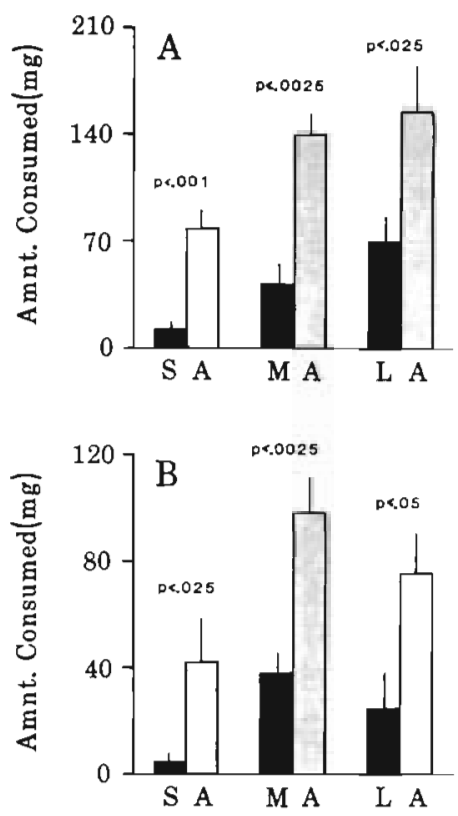

Fig. 2. (A) Littorina sitkana and (B) L. scutulata preferences for short (S), medium (M) and long (L) adventitious branches and apical meristematic tissue (A). Consumption rates are given as the mean amount of tissue consumed (in $\mathrm{mg}$ ) $\pm 1 \mathrm{SE}$ from 8 replicate experiments. $p$-values are from a Student's $t$-test comparing the relative differences in mass changes between apices and adventitious branches during the feeding experiments (Sokal \& Rohlf 1981)

Littorina sitkana (Fig. 2A) and L. scutulata (Fig. 2B) preferred ( $p<0.05$ using a Student's $t$-test) apices over adventitious branch tissue. $L$. sitkana consumed apices ca 6 times as much as short adventitious branches, 3 times as much as medium adventitious branches, and twice as much as long adventitious branches. Consumption rates of apices by $L$. scutulata were about 10 times greater than those of short adventitious branches, and 3 times those of medium and long adventitious branches. There were no significant differences in con-
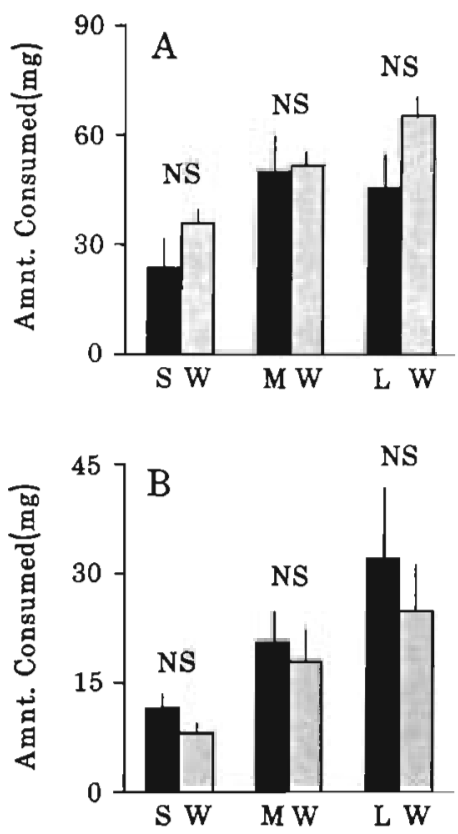

Fig. 3. (A) Littorina sitkana and (B) L. scutulata preferences for short (S), medium (M) and long (L) adventitious branches and wing tissue $(\mathrm{W})$. Consumption rates are given as the mean amount of tissue consumed (in $\mathrm{mg}$ ) $\pm 1 \mathrm{SE}$ from 16 replicate experiments. $p$-values are from Student's $t$-test comparing the relative differences in mass changes between wings and adventitious branches during the feeding experiments (Sokal \& Rohlf 1981). NS: $p>0.05$

sumption rates by either littorine snail between adventitious branches and wing tissues (Fig. 3). Consumption rates of apices by $L$. sitkana were 3 times those of wing tissues (Fig. 4). L. scutulata consumed twice as much apical meristem tissue as wing tissue.

Concentrations of phenolic compounds in adventitious branches were highest in short adventitious branches (Table 4) and decreased as these structures

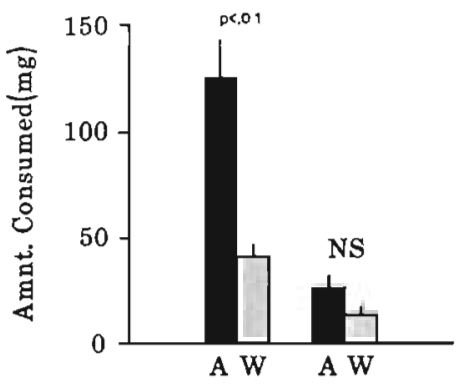

L. sitk. L. scut.

Fig. 4. Consumption rates of Littorina sitkana and L. scutulata for wings (W) and apical meristems (A) of Fucus distichus. Consumption rates are given as the mean amount of tissue consumed (in $\mathrm{mg}$ ) $\pm 1 \mathrm{SE}$ from 16 replicate experiments. $p$ values are from a Student's $t$-test comparing the relative differences in mass changes between wings and adventitious branches during the feeding experiments (Sokal \& Rohlf 1981). NS: $p>0.05$ 
Table 4. Fucus distichus. Phenolic concentrations (as \% of dry weight) in adventitious branches and apical meristematic tissues. Values are given as means of 10 replicate measurements \pm $1 \mathrm{SE}$. These values are significantly different using a 1 -way analysis of variance $(F=8.4593, p<0.001)$. Stain reaction indicates the results of staining extracts run on Thin Layer Chromatography plates with Lindt s Reagent, a stain specific for phloroglucinol derivatives. + : positive reaction; - : no reaction

\begin{tabular}{|lccc|}
\hline Tissue type & $\begin{array}{c}\text { Phenolic } \\
\text { concen- } \\
\text { tration }\end{array}$ & $N$ & $\begin{array}{c}\text { Stain } \\
\text { reac- } \\
\text { tion }\end{array}$ \\
\hline $\begin{array}{l}\text { Short adventitious branches } \\
\quad 1<1 \mathrm{~cm} \text { long) }\end{array}$ & $5.68 \pm 1.72$ & 10 & + \\
$\begin{array}{l}\text { Medium adventitious branches } \\
\quad(1 \text { to } 2 \text { cm long) }\end{array}$ & $4.53 \pm 1.93$ & 10 & + \\
$\begin{array}{l}\text { Long adventitious branches } \\
(2 \text { to } 3 \text { cm long) }\end{array}$ & $3.73 \pm 1.01$ & 10 & + \\
$\begin{array}{l}\text { Apical meristems } \\
\text { Wings }\end{array}$ & $3.41 \pm 0.48$ & 9 & + \\
\hline
\end{tabular}

increased in length. Medium adventitious branches had $20 \%$ lower levels of polyphenolics than did short adventitious branches. Long adventitious branches had about $40 \%$ lower concentrations. Concentrations of phenolics in short and medium adventitious branches and in medium and long adventitious branches were indistinguishable ( $p>0.05$ using an SNK analysis). Phenolic concentrations of apices were comparable to those in long adventitious branches, whereas wing tissues had phenolic levels that were about $18 \%$ greater than those found in short adventitious branches.

\section{DISCUSSION}

In Fucus distichus, adventitious branches are induced by damage to the thallus of the plant. In field experiments, clipping the apices of the thallus stimulated the formation of these structures. In laboratory experiments, the production of adventitious branching has been induced by cutting Fucus midribs (Fulcher \& McCully 1969). Thus, the production of adventitious branches can be caused by mechanical damage and does not require the presence of herbivores. However, field observations suggest that most of the damage in $F$. distichus tissues seen at Tatoosh Island was caused by grazing from the 2 littorine snails, Littorina sitkand and L. scutulata. Thus, most of the adventitious branches on $F$. distichus at Tatoosh probably result from damage due to littorine grazing. The site at which the field measurements of adventitious branches were taken, the main beach on Tatoosh Island, is protected from most heavy wave action. Therefore, it is unlikely that the damage that these plants receive is due to abrasion from objects moved by water. The mean number of adventitious branches on plants is positively correlated with herbivore density, further suggesting that the formation of adventitious branches is a result of damage by herbivores; adventitious branches were not found on plants which showed no signs of herbivore damage. Although adventitious branches on Tatoosh Island appear to have be formed primarily in response to herbivore damage, their formation may also be induced by mechanical damage, such as that produce by waves at other locations.

Adventitious branches represent a previously undescribed form of defense against marine herbivores. Algal morphological defenses include thallus shape and form (Littler \& Littler 1980, Hay 1981, Steneck \& Watling 1982, Taylor \& Hay 1984), production of heteromorphic thalli (Lubchenco \& Cubit 1980), thallus toughness (Watson \& Norton 1985a, b) and the production of protuberances (Steneck \& Paine unpubl.), spines (K. Van Alstyne \& V. Paul unpubl.) and cuticles (Gaines 1985). Adventitious branches may arise because damage to the thallus changes the relationships between cells in a way that causes the production of meristematic cells. Alternatively, they may have been selected for as a way of producing new tissues that are grazerresistant.

Consumer-induced morphological defenses have been previously described in only a few marine organisms. For example, Padina jamaicensis, a tropical brown alga, produces a turf-like morphology in response to grazing by herbivorous fish (Lewis et al. 1987). The encrusting bryozoan Membranipora membranacea induces spine production in response to a chemical cue provided by the nudibranch predator Doridella steinbergae (Harvell 1984, 1985, 1986). The intertidal barnacle Chthamalus anisopoma responds to the presence of the carnivorous gastropod Acanthina angelica by growing in a bent morphology which reduces further predation by the snail (Lively $1986 a$, b). In addition, induced morphological defenses have been well documented in several species of freshwater zooplankton. Rotifers and Daphnia have widely varying morphologies which are environmentally induced, either through the presence of predators or by chemical cues obtained dietarily (Havel 1986). Fucus distichus is the only marine organism in which predator-induced chemical defenses have been described (Van Alstyne 1988a).

Adventitious branches provide a method for proliferating numerous branches from a non-apical part of the plant. If the thallus is likely to break at the point where the plant is wounded, then the production of adventitious branches would allow the proliferation of new tissues at or below the point of injury. Multiple branch production may cause some self-shading in these tissues although this may not be detrimental to a 
high intertidal alga. Observations of adventitious branches in the field suggest that they can become reproductive at a small size ( 5 to $10 \mathrm{~cm}$ long). Thus, multiple branch production may allow the alga to produce large numbers of gametes relatively quickly under the unfavorable condition of intense herbivory. Additionally, adventitious branch production often occurs from small plants that have been entirely grazed back to the midrib. In these plants, all blade and meristematic tissue is removed by herbivores and adventitious branches provide a mechanism for the generation of new meristem.

Adventitious branches contain higher levels of polyphenolic compounds than do apices; however, phenolic levels of these structures are not as high as those found in wing tissue. Brown algal polyphenolic compounds have been shown to be feeding deterrents towards herbivorous gastropods and urchins, including Littorina littorea in New England, USA (Geiselman \& McConnell 1981, Steinberg in press). The high levels of phenolic compounds may contribute to adventitious branches being less preferred by Littorina spp. than are apices. However, morphological characteristics of adventitious branches, such as branch clumping, and thallus shape, thickness, and toughness, undoubtedly also contribute to their being a low preference food (Van Alstyne 1988b).

Adventitious branching in Fucus appears to be analogous to adventitious shoot production by terrestrial trees. Bryant $(1981,1982)$ demonstrated that like adventitious branches, adventitious shoots are less palatable and better defended chemically than are mature growth twigs. He postulates that herbivoreinduced changes in levels of defensive compounds in these shoots may be responsible for $10 \mathrm{yr}$ cycles in snowshoe hare populations. It is unlikely that adventitious branch production by Fucus has a significant effect on littorine populations since these snails do not appear to be food limited (Behrens 1972); however, they probably do have an impact on the fitness of the plants producing them, by reducing grazing on newly growing tissues.

In summary, adventitious branches appear to function as an herbivore-induced defense, occurring in response to wounds inflicted by grazing and reducing the susceptibility of regenerating tissues from further attacks by grazers. The tissue reorganization that occurs when Fucus distichus is wounded results in the formation of numerous proliferating branches each growing from a newly formed apex. Thus, the individual branches in an adventitious branch can be considered equivalent to single apical meristems. The results of these feeding experiments indicate that adventitious branches are less susceptible to herbivore attacks than are ordinary apical meristematic tissue.
Acknowledgements. Thanks are due to T Daniel, P. Kareiva, R. Paine, V Paul, S. Williams and 5 anonymous reviewers for their comments on this manuscript. I also thank the Makah Tribal Council for allowing me access to Tatoosh Island and D. Willows and the staff at the Friddy Harbor Marine Lab for providing laboratory facilities. This study was supported by NSF grant OCE 84-15707 to R. Paine, Whitehall Foundation grant \#83548 to D. Rhoades and by an NSF Predoctoral Fellowship and grants from the Lerner Grey Fund for Marine Research and Sigma Xi to K.L.V

\section{LITERATURE CITED}

Anderson, R. J., Velimirov, B. (1982). An experimental investigation of the palatability of kelp bed algae to the sea urchin Parechinus angulosus, Leske. P.S.Z.N.I.: Mar. Ecol. 3: $357-373$

Behrens, S. (1972). The role of wave impact and desiccation on the distribution of Littorina sitkana Philippi, 1845. Veliger 15: $129-132$

Bryant, J. P. (1981). Phytochemical deterrence of snowshoe hare browsing by adventitious shoots of four Alaskan trees. Science 213: 889-890

Bryant, J. P. (1982). The regulation of snowshoe hare feeding behavior during winter by plant antiherbivore chemistry. Proc internat. Lagomorph Conf. 1-720-731

Fritsch, F. E. (1959). The structure and reproduction of the algae. Vol. II Cambridge University Press, London

Fulcher, R. G., McCully, M. E. (1969). Histological studies on the genus Fucus. IV. Regeneration and adventive enbryony. Can. J. Bot. 47: 1643-1649

Fulcher, R. G., McCully, M. E. (1971). Histological studies on the genus Fucus. V An autoradiographic and electron microscopic study of the early stages of regeneration. Can. J. Bot. 49: 161-165

Gaines, S. D. (1985). Herbivory and between-habitat diversity the differential effectiveness of plant defenses in a marine plant. Ecology 66: 473-485

Geiselman, J. A. (1980). Ecology of chemical defenses of algae against the herbivorous snail, Littorina littorea, in the New England rocky intertidal community. Ph. D. thesis, Woods Hole Oceanographic Institution/Massachusetts Institute of Technology

Geiselman, J. A., McConnell, O. J. (1981). Polyphenols in brown algae Fucus vesiculosus and Ascophyllum nodosum: chemical defenses against the marine herbivorous snail, Littorina littorea. J. chem. Ecol. 7: 1115-1133

Gilbert, J. J. (1966). Rotifer ecology and embryological induction. Science 151 - 1234-1237

Gilbert, J. J. (1967). Asplanchna and postero-lateral spine production in Brachionus calyciflorus. Arch. Hydrobiol. 64: $1-62$

Gilbert, J. J. (1980). Developmental polymorphism in the rotifer Asplanchna sieboldi. Am. Scient. 68: 636-646

Harborne, J. B. (1982). Introduction to ecological biochemistry. Academic Press, London

Harborne, J. B. (1986). Recent advances in chemical ecology. Nat. Product Rep. (Lond.) 1986: 323-344

Harvell, C. D. (1984). Predator-induced defense in a marine bryozoan. Science 224: 1357-1359

Harvell, C. D. (1985). Partial predation, inducible defenses, and the population biology of a marine bryozoan (Membranipora membranacea). Ph. D. thesis, University of Washington, Seattle

Harvell, C. D. (1986). The ecology and evolution of inducible 
defenses in a marine bryozoan: cues, costs, and consequences. Am. Nat. 128: 810-823

Havel, J. (1986). Predator-induced defenses: a review. In Kerfoot, W. C., Sih, A. (eds.) Predation: direct and indirect effects on aquatic communities. Univ. Press of New England, Hanover, p. 263-278

Hay, M. E. (1981). The functional morphology of turf-forming seaweeds: persistence in stressful marine habitats. Ecology 62: 739-750

Hay, M. E., Fenical, W. (1988). Chemically mediated seaweed herbivore interactions. Ann. Rev. Ecol. Syst. 19 $111-145$

Lewis, S. M., Norris, J. N., Searles, R. B. (1987). The regulation of morphological plasticity in tropical reef algae by herbivory. Ecology 68: 636-641

Littler, M. M., Littler, D. (1980). The evolution of thallus form and survival strategies in benthic marine macroalgae: field and laboratory test of a functional form model. Am. Nat. 116: $25-44$

Lively, C. M. (1986a). Competition, comparative life histories, and maintenance of shell dimorphism in a barnacle. Ecology $67: 858-864$

Lively, C. M. (1986b). Predator-induced shell dimorphism in the acorn barnacle Chthamalus anisopoma. Evolution 40 : $232-242$

Lubchenco, J., Cubit, J. (1980). Heteromorphic life histories of certain marine algae as adaptations to variations in herbivory. Ecology 61: 676-687

McLachlan, J., Chen, L. C.-M. (1972). Formation of adventive embryos from rhizoidal filaments in sporelings of four species of Fucus (Phaeophyceae). Can. J. Bot. 50: $1841-1844$

Moss, B. L. (1961). Wound healing and regeneration in Fucus vesiculosus $\mathrm{L}$. Proc int. Seaweed Symp. 4: 117-122

Oltmanns, F. (1904). Morphologie und Biologie der Algen. Vol. 1 Fischer, Jena

Peterson, P., Renaud, P. (in press). Analysis of feeding preference experiments. Oecologia (Berl.)

Ragan, M. A., Craigie, J. S. (1978). Phenolic compounds in brown and red algae. In: Hellebust, J. A., Craigie, J. S. (eds.) Handbook of phycological methods, Vol. II. Cambridge Univ. Press, Cambridge, p. 157-179

Ragan, M. A., Glombitza, K. (1986). Phlorotannins, brown algal polyphenols. In: Round, F. E., Chapman, D. J. (eds.)

This article was submitted to the editor
Progress in phycological research, Vol. 4. Biopress, p. $129-241$

Rhoades, D. F. (1979). Evolution of plant chemical defense against herbivores. In. Rosenthal, G. A., Janzen, D. H. (eds.) Herbivores: their interaction with secondary plant metabolites. Academic Press, New York, p 1-55

Rosenthal, G. A., Janzen, D. H. (1979). Herbivores: their interaction with secondary plant metabolites. Academic Press, New York

Sokal, R. R., Rohlf, F. J. (1981). Biometry. W. H. Freeman and Co., New York

Steinberg, P. D. (1985). Feeding preferences of Tegula funebralis and chemical defenses of marine brown algae. Ecol. Monogr. 55: 333-349

Steinberg, P. D. (in press). The effects of quantitative and qualitative variation in phenolic compounds on feeding in three species of marine invertebrate herbivores. J. exp. mar. Biol. Ecol.

Steneck, R. S., Watling L. (1982). Feeding capabilities and limitations of herbivorous molluscs: a functional group approach. Mar. Biol. 68: 299-319

Steward, F. C. (1968). Growth and organization in plants. Addison-Wesley, Reading

Swain, T S., Goldstein, J. L. (1964). The quantitative analysis of phenolic compounds. In: Pridham, J. B. (ed.) Methods in polyphenol chemistry. MacMillan, New York, p. 131-146

Taylor, P. R., Hay, M. E. (1984). Functional morphology of intertidal seaweeds: adaptive significance of aggregate vs. solitary forms. Mar. Ecol. Prog. Ser. 18: 295-302

Van Alstyne, K. L. (1988a). Herbivore grazing increases polyphenolic defenses in the intertidal brown alga Fucus distichus. Ecology 69: 655-663

Van Alstyne, K. L. (1988b). The ecology and evolution of antiherbivore defenses in fucoid brown algae. Ph. D thesis. Univ, of Washington, Seattle

Van Alstyne, K. L., Paul, V. J. (1988). The role of secondary metabolites in mediating ecological interactions. Proc. 6th int. Coral Reefs Congr (in press)

Watson, D. C., Norton, T A. (1985a). Dietary preferences of the common periwinkle, Littorina littorea (L.). J. exp. mar Biol. Ecol. 88: 1-19

Watson, D. C., Norton, T. A. (1985b). The physical characteristics of seaweed thalli as deterrents to littorine grazers. Botanica mar. 28: 383-387

Manuscript first received: January 10, 1989

Revised version accepted: April 14, 1989 